\title{
FACTORS AFFECTING THE PERFORMANCE OF GRAIN COOPERATIVE SOCIETIES IN LATVIA
}

\author{
Janis Mistris' ${ }^{1}$, Baiba Mistre ${ }^{2}$, Anda Zvaigzne ${ }^{3}$ \\ ${ }^{1}$ Mg.oec., Mg.ing., Latvia University of Life Sciences and Technologies, Jelgava, Latvia, e- \\ mail: janis.mistris@inbox.lv \\ ${ }^{2}$ Mg.oec., Institute of Finance and Accounting, Latvia University of Life Sciences and \\ Technologies, Jelgava, Latvia, e-mail: Baiba.Mistre@llu.lv \\ ${ }^{2}$ Dr.oec. associate professor, leading researcher, Rezekne Academy of Technologies, \\ Rezekne, Latvia, e-mail: Anda.Zvaigzne@rta.lv
}

Received: 8 June 2020 / Revised: 14 June / Accepted: 10 July 2020 /

Published: 30 November 2020

\begin{abstract}
The present research continues and complements previous research by the authors on the performance of grain cooperative societies in Latvia.

The research aim is to identify and assess the factors affecting the performance of grain cooperative societies in Latvia.

The research results revealed that the main endogenous factor hindering the performance of grain cooperatives was technological - underdeveloped grain processing -, as the cooperatives did not own processing enterprises, which was mainly due to an unclear situation in the sales market. The industry experts referred to the socio-economic factor as the key opportunity for improving the performance of cooperative societies - cooperation between small cooperative societies and large ones within the industry -, as well as the promotion of cooperation with scientists, technological progress and the positive effects on industry development in the country and the region. The research results revealed that the main threat to the development of cooperative societies was the political factor - possible sudden and significant changes in the national agricultural policy, which might be affected by the turnover of policy makers and the priorities set for the industry, as well as the economic situation in the country.

The research employed the following methods: monographic, induction and deduction, graphical, comparison, a sociological research method - structured expert surveying -, SWOT analysis, pairwise analysis and statistical analysis.
\end{abstract}

Keywords: cooperative societies, expert rating, factors.

JEL code: $01, R O$.

\section{Introduction}

The research topic is relevant and important, as cooperation promotes the development of agriculture in the country. The National Development Plan of Latvia 2014-2020 states that the promotion of cooperation in agriculture is one of the national priorities, which means that agricultural policies in Latvia focus on the development of cooperation (Latvijas Republikas Saeima, 2012).

In the world, the turnover of agricultural and food cooperatives accounted for $33 \%$ of the total turnover of cooperatives. There were 3 million cooperatives, which employed 280 million individuals, making up 
$10 \%$ of the total workforce (ICA \& EURICSE, 2018). In terms of turnover, agricultural cooperatives ranked first in the European Union and accounted for $39 \%$ of the total turnover of cooperatives (Cooperatives: Characteristics, activities..., 2019)

Grain cooperative societies are affected by various factors that need to be identified and assessed in order for the cooperative societies to be able to draw up action plans in future and reduce the impacts of the factors or adapt their activities.

The research aim is to identify and assess the factors affecting the performance of grain cooperative societies in Latvia.

Specific research tasks:

1. To examine the theoretical aspects of cooperative performance;

2. To identify the most important factors affecting the performance of cooperative societies.

The research put forward the following hypothesis: the performance of grain cooperative societies is affected by various social, economic, technological and political factors.

The research employed the following methods: monographic, induction and deduction, graphical, comparison, a sociological research method structured expert surveying -, SWOT analysis, pairwise analysis and statistical analysis (averages, coefficients of variation).

The research employed scientific research papers from various databases, reports on agriculture, as well as the results obtained from expert questionnaires, other publicly available information in the library and Internet resources.

\section{Literature review}

Theoretical research shows that the origins of cooperation relate to improving the financial situation of the poorest people. In a situation where a very large part of the society was at risk of poverty, mutual cooperation provided an opportunity to save financial resources as well as united the society.

The term cooperation comes from the Latin word cooperation meaning working together, participation, collaboration (Vedla, 2000). The concept of cooperation has been widely researched, and various explanations for it could be found. J. Kučinskis (2004) has compiled definitions of the concept of cooperation given by authors (E. Balodis, R. Oven, Š. Žida, P. Kaufman, C. Fux, D. Bansel, V. Pekarsky, M. Tuhan-Baranovskyi, V. Pose, V. Totomianc) from various European countries (Kučinskis, 2004). All the definitions emphasize the idea of mutual benefit for the members and adherence to the principles of volunteering and increasing the level of material wellbeing (Kučinskis, 
2004).

In their research paper Development of Agricultural Cooperation in Zemgale Region, V. Bugina and K. Pabērza (2007) pointed out that A. Miglavs has given a comprehensive and complete explanation of the term cooperation. A. Miglavs stressed that cooperation is an activity where several persons with common interests come together to achieve a common goal (Bugina, Pabērza, 2007).

L. Gyulgyulyan and I. Bobojonov (2019) have examined the explanations of the concept of cooperation given by a number of international organizations. According to a definition by the International Cooperative Alliance, an agricultural cooperative is an autonomous association of persons who voluntarily unite to meet their common economic, social and cultural needs and aspirations through a jointly owned and democratically controlled enterprise. The authors emphasize that any international organization have similar basic principles of cooperation (Gyulgyulyan, Bobojonov, 2019).

According to the Cooperative Societies Law, a cooperative society a voluntary association of persons aiming to contribute to the effective implementation of the common economic interests of the members (Cooperatives: Characteristics, activities..., 2019). The term cooperative is widespread in daily use. In accordance with the national regulatory framework, agricultural cooperatives could be classified by agricultural industry, for example, grain, dairy, vegetable etc. (Latvijas Republikas Saeima, 2019).

The historical evolution of national cooperation has been affected by the development of cooperation in other European countries. Cooperatives were strongly developed in the pre-war Latvia, which was later devastated by the Soviet occupation (Bugina, Pabērza, 2007). Pre-war national cooperation was strongly influenced by the strong Danish cooperative movement in the pig and dairy industries (Balodis, 1934).

The very first agricultural cooperatives or associations established in Latvia carried out an educational mission, disseminating knowledge and delivering various courses and lectures, organizing agricultural schools, specialized libraries, selection and testing fields, the exchange of best practices, exhibitions and various competitions - the winners were rewarded, and leisure and entertainment activities that fostered a spirit of togetherness and community facilitated the establishment of valuable contacts in informal settings. Historically, the main goal of agricultural cooperatives was to provide their members with all the means of production necessary for the successful operation of the cooperatives. Central to the supply chain was the ability to supply machinery, fertilizers, seeds, feed for livestock and other commodities needed for basic production at reasonable 
market prices. Initially, this function was performed by consumer associations, which emerged earlier than agricultural cooperatives did, and their basic principle was very simple: by uniting a certain number of farmers, it is possible to purchase a large quantity of goods, thereby setting the price (Kučinskis, 2004; Balodis, 1934).

\section{Methodology}

The research employed the monographic and descriptive methods that allowed the authors to get a detailed notion of the problem researched from a theoretical perspective based on an extensive review of the relevant scientific literature. The research also employed the following other methods: induction and deduction, the graphical method, comparison, statistical analysis and a sociological research method - structured expert surveying and interviewing.

The structured expert survey was conducted to identify the most significant factors affecting the performance of grain cooperatives. The survey involved seven experts who were competent in the grain production industry and were engaged in operating cooperatives. The experts represented the Latvian Agricultural Cooperatives Association, the Agricultural Services Cooperative Society (ASCS) Latraps and the ASCS VAKS. For confidentiality purposes and at the request of the experts, the identities of the experts are not disclosed in the research.

\section{Research results}

The research performed an analysis of strengths, weaknesses, opportunities and threats, in which the strengths and weaknesses of as well as opportunities and threats for grain cooperatives were summarized (see Table 1).

The SWOT analysis revealed the impacts of various endogenous and exogenous, social, economic, technological and political factors on the performance of grain cooperatives, which interacted and were strongly related to each other.

To identify the most important social, economic, political and technological factors affecting the performance of grain cooperatives, seven experts who were competent in the grain production industry and were engaged in operating cooperatives were involved in the survey. The experts represented the Latvian Agricultural Cooperatives Association, the Agricultural Services Cooperative Society (ASCS) Latraps and the ASCS VAKS. For confidentiality purposes and at the request of the experts, the identities of the experts are not disclosed in the research. 
Table 1. Analysis of the endogenous and exogenous factors affecting the performance of grain cooperatives in Latvia (authors' construction based on the structured expert survey $(n=7)$ and a pairwise analysis)

\begin{tabular}{|l|}
\hline \multicolumn{2}{|c|}{ Endogenou } \\
\hline - Cooperative members get a higher price \\
on their products produced. \\
- Cooperative provides protection of the \\
members from large companies, \\
monopolies, ensuring social support and \\
assistance. \\
- Cooperation provides support related to \\
production, supply, transport and storage, \\
processing and marketing of products. \\
- Cooperative promotes \\
modernization. \\
- Cooperative provides the members with \\
educational seminars and other training \\
or experience exchange. \\
- Cooperative provides support to the \\
members by means of competent \\
specialists (agronomists, accountants \\
etc.). \\
- Cooperative unites the farmers who are \\
members of one cooperative, thereby \\
promoting mutual cooperation among the \\
members.
\end{tabular}

Exogenous factors

\begin{tabular}{|l|l|}
\hline \multicolumn{2}{|c|}{ Opportunities } \\
\hline - Merger of small cooperatives or
\end{tabular} cooperation with large cooperatives within the industry.

- Promotion of the cooperative name.

- Promotion of the idea of cooperation.

- Promotion of second level cooperation.

- Promotion of cooperatives at the level of the Baltic States.

- Cooperatives promote cooperation with scientists, technological progress and the positive effects on industry development in the country/region.

- Cooperatives contribute to making the regulatory framework of the industry more complete in the country.
- Agricultural processing by cooperatives is underdeveloped.
- Low involvement of large farmers in cooperatives.

-Weak cooperative member loyalty.

- Lack of qualified managers.

- Poor fulfilment of the member's obligations towards the cooperative.

- Uneven availability of cooperative services in the country.

- Low involvement of small and medium farmers in the cooperative.

- Insufficient range of cooperative services (equipment rental).

- Choice of a sales strategy for grain trading on stock exchanges.

- Membership of a cooperative does not guarantee the availability of all cooperative services, e.g. purchase of grain supply quotas.

- Members' lack of understanding of the need for a highly qualified cooperative management.

- Tax policy.
- Sudden and significant changes in the
national agricultural policy.
- Insufficient national support to protect
the internal market from foreign
competitors.
- Policy implemented by financial
development institutions.
- Common EU policy on GHG emissions.
- Bank support policies.
- Global crises (financial crises,
pandemics, military conflicts etc.).
- Well-developed large grain processing
companies.
- Farmers' rejection of cooperation.


A questionnaire, in which the questions were arranged using the pairwise analysis method, was developed based on the SWOT analysis. A structured survey of the experts was then conducted. In each pair of questions, each expert selected and ticked the factor that was more important than the other.

Summarizing the answers provided by the experts, an average value was calculated for each factor, which showed the importance of the factor, as well as the coefficient of variation, which was one of the indicators of variance. The lower the coefficient of variation was, the lower the dispersion of the variable around the arithmetic mean was observed (Arhipova, Bāliṇa, 2006).

The results of the expert survey showed that the main strength of cooperatives was the economic and technological support provided by the cooperatives related to production, supply, transport and storage, processing and marketing of products (see Figure 1). The coefficient of variation calculated for this factor was $16 \%$, which showed that the opinions of the experts on this group of criteria were unanimous, and it was the second-lowest value of the coefficient of variation for the strengths.

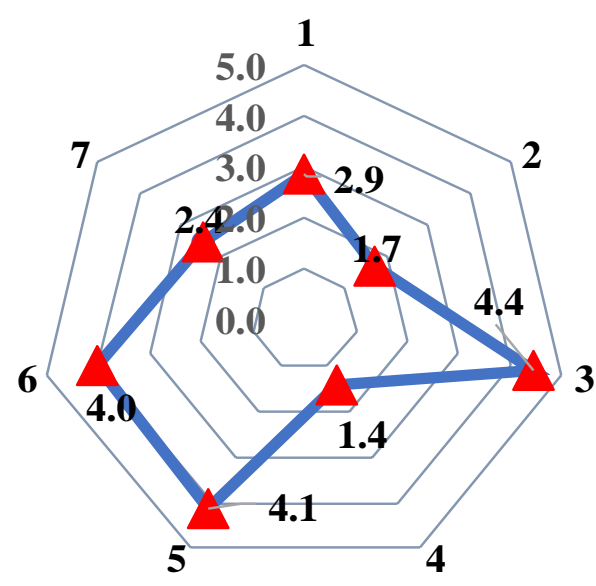

Fig. 1. Average numerical values for the strengths of endogenous factors affecting the performance of grain cooperatives calculated by the pairwise analysis method (authors' construction based on the structured expert survey ( $n=7)$ and a pairwise analysis) 
Ten farmers engaged in grain production were surveyed within the thematic assessment Development of Cooperation in Agriculture; the farmers emphasised the opportunity to market their products as the main reason for becoming a member of the cooperative (Kooperācijas attīstība ...., 2012). The research results showed that farmers' views on the benefits of being a member of a cooperative have not changed.

The experts gave high ratings to the opportunity to use seminars and other kinds of training held by a cooperative. The coefficient of variation for this factor was $35 \%$, which showed that the opinions of the experts differed. More of these factors, compared with the other factors, were chosen by the experts engaged in the management of a cooperative and representing the Latvian Agricultural Cooperatives Association. The experts representing farmers chose this factor less often. The opportunity to use the services of highly qualified specialists was also highly rated, and the ratings of this factor had the highest coefficient of variation of $13 \%$.

The opinions of the experts in the rating of individual factors were very different, which was revealed by the coefficients of variation. The choices of the experts varied for the following factors: cooperative members get a higher price on their products produced and a cooperative provides protection of the members from large companies, monopolies, ensuring social support and assistance. The coefficients of variation for the mentioned factors were $85 \%$ and $87 \%$, respectively. The experts who represented cooperative managements did not consider that membership of a cooperative ensured a higher price on the products produced.

The experts emphasized the endogenous technological factor of the specific field - underdeveloped grain processing - as the main negative factor (see Figure 2). Some experts had different opinions concerning this factor. The coefficient of variation for this factor was the lowest - $29 \%-$ in the rating of weaknesses. The development strategy for agricultural and forestry service cooperative societies for 2021-2027 designed by the Latvian Agricultural Cooperatives Association states that one of the priorities is the promotion of agricultural processing by cooperatives (LLKA, 2019).

In relation to the weaknesses of cooperatives, the experts also indicated the following socio-economic factors: a lack of qualified managers, cooperative members' lack of understanding of the need for a highly qualified cooperative management and poor fulfilment of the member's obligations towards the cooperative. The coefficient of variation for the factor concerning member loyalty was $73 \%$, indicating the different opinions of the experts on this matter. The cooperative managers stressed that the cooperative member loyalty was weak; for this reason, the authors of the present research recommend cooperatives to design and introduce 
educational measures for increasing the loyalty of their members in the future.

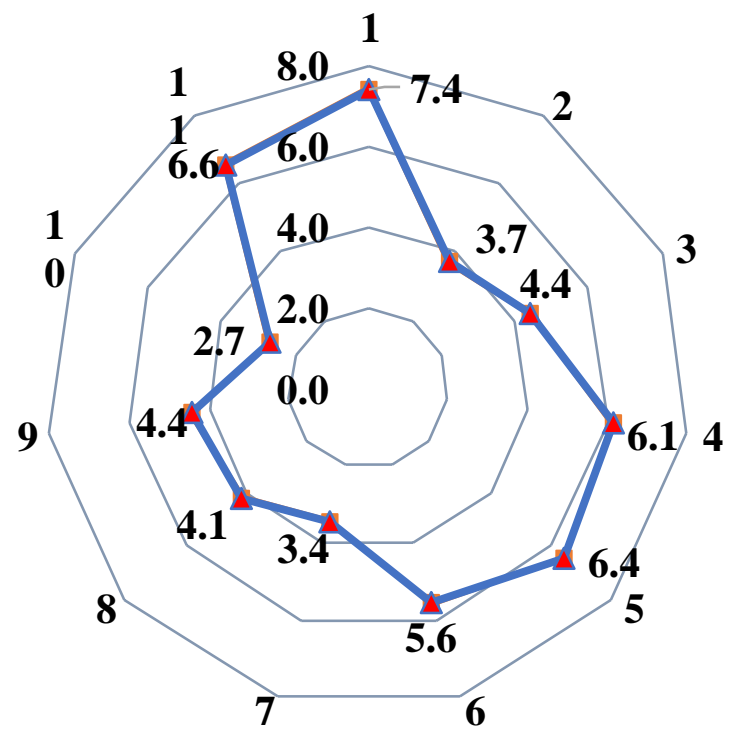

1. Agricultural processing by cooperatives is underdeveloped.

2. Low involvement of large farmers in cooperatives.

3. Weak cooperative member loyalty.

4. Lack of qualified managers.

5. Poor fulfilment of the member's obligations towards the cooperative.

6. Uneven availability of cooperative services in the country.

7. Low involvement of small and medium farmers in the cooperative.

8. Insufficient range of cooperative services (equipment rental).

9. Choice of a sales strategy for grain trading on stock exchanges.

10. Membership of a cooperative does not guarantee the availability of all cooperative services, e.g. purchase of grain supply quotas.

11. Members' lack of understanding of the need for a highly qualified cooperative management.

\section{Fig. 2. Average numerical values for the weaknesses of endogenous factors affecting the performance of grain cooperatives calculated by the pairwise analysis method (authors' construction based on the structured expert survey ( $n=7)$ and a pairwise analysis)}

The most important opportunities, in the experts' opinion, were cooperation between small and large cooperatives, cooperation with scientists, technological progress and the positive effects on industry development, as well as the opportunity to promote cooperation at the level of the Baltic States (see Figure 3). 


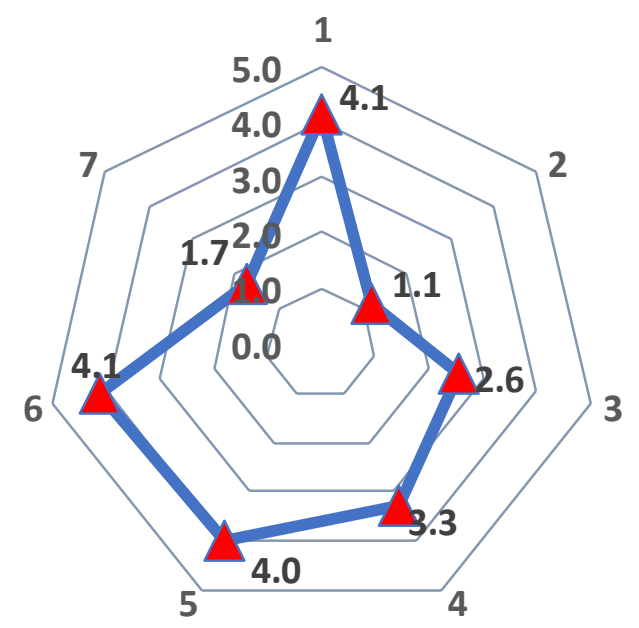

1. Merger of small cooperatives or cooperation with large cooperatives within the industry.

2. Promotion of the cooperative name.

3. Promotion of the idea of cooperation.

4. Promotion of second level cooperation.

5. Promotion of cooperatives at the level of the Baltic States.

6. Cooperatives promote cooperation with scientists, technological progress and the positive effects on industry development in the country/region.

7. Cooperatives contribute to making the regulatory framework of the industry more complete in the country

Fig. 3. Average numerical values for the opportunities of exogenous factors affecting the performance of grain cooperatives calculated by the pairwise analysis method (authors' construction based on the structured expert survey ( $n=7)$ and a pairwise analysis)

The coefficients of variation ranged from $23 \%$ to $30 \%$ for all the three factors, which were the highest values. The experts' opinions on all the remaining factors differed. Average ratings were given to the social factor related to the promotion of the idea of cooperation. The authors believe that the ratings should be higher because more attention should be paid to the promotion of the idea of cooperation.

In the rating of external treats, the experts considered the political factor to be the most important one, i.e. sudden and significant changes in the national agricultural policy (see Figure 4). In the rating of this factor, the experts had very similar opinions, as evidenced by the coefficient of variation of $13 \%$. 


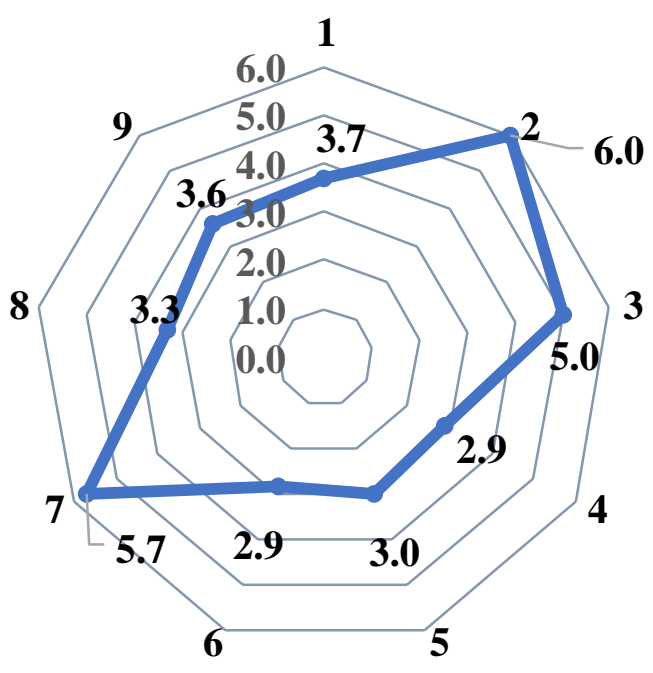

1. Tax policy.

2. Sudden and significant changes in the national agricultural policy.

3. Insufficient national support to protect the internal market from foreign competitors.

4. Policy implemented by financial development institutions.

5. Common EU policy on GHG emissions.

6. Bank support policies.

7. Global crises (financial crises, pandemics, military conflicts etc.).

8. Well-developed large grain processing companies.

9. Farmers' rejection of cooperation

Fig. 4. Average numerical values for the threats of exogenous factors affecting the performance of grain cooperatives calculated by the pairwise analysis method (authors' construction based on the structured expert survey $(\mathrm{n}=7)$ and a pairwise analysis)

High ratings were given to the following socio-economic factors: global crises and insufficient national support to protect the internal market from foreign competitors, with the coefficients of variation being $38 \%$ and $24 \%$, respectively. It indicates that the experts were more divided on the issue of global crises. The authors believe that this is due to the current global situation with the Covid-19 pandemic. The experts differed in their ratings of all the remaining threats.

\section{Conclusions}

1. Theoretical research shows that the origins of cooperation relate to improving the financial situation of the poorest people. The nature, development and significance of cooperation have been extensively studied in the scientific literature.

2. The SWOT analysis done in the research revealed that the dominant strengths in the performance of cooperatives were the facts that a cooperative provides support related to production, supply, transport and storage, processing and marketing of products as well as competent specialists could be hired and the availability of educational seminars.

3. According to the industry experts, the main endogenous factor hindering the performance of grain cooperatives was technological underdeveloped grain processing -, as the cooperatives did not own processing enterprises, which was mainly due to an unclear situation in the sales market. 
4. The industry experts referred to the socio-economic factor as the key opportunity for improving the performance of cooperative societies cooperation between small cooperative societies and large ones within the industry -, as well as the promotion of cooperation with scientists, technological progress and the positive effects on industry development in the country and the region.

5. The industry experts believed the political factor was the main threat to the development of cooperative societies - possible sudden and significant changes in the national agricultural policy, which might be affected by the turnover of policy makers and the priorities set for the industry, as well as the economic situation in the country.

6. The hypothesis put forward proved to be true, as the analysis revealed that the performance of grain cooperatives was affected by various social, economic, technological and political factors.

7. The managements of grain cooperatives need to increase the loyalty of their cooperative members by holding various educational activities, thereby contributing to cooperative development in the grain industry.

\section{References}

1. Arhipova, I., Bāliṇa S. (2006). Statistika ekonomikā un biznesā. Rīga: Datorzinību Centrs.

2. Balodis, E. (1934). Kooperācija. Rīga: Latvijas kooperatīvu izdevniecības savienības apgādībā.

3. Bugina, V., Pabērza, K. (2007). The Development of Cooperation in Agriculture in Zemgale Region. Economic Science for Rural Development proceedings of the international scientific conference, No 13. Jelgava: LLU, 115-123.

4. Cooperatives: Characteristics, activities, status, challenges (2019). European Parliamentary Research Service. Retrieved from https://www.europarl.europa.eu/RegData/etudes/BRIE/2019/635541/EPRS BRIC 2019)635541 EN.pdf

5. Gyulgyulyan, L., Bobojonov, I. (2019). Factors Influencing On Participation To Agricultural Cooperatives In Armenia. Regional Science Inquiry. 11(1), 121-134. Retrieved from http://www.rsijournal.eu/ARTICLES/June 2019/RSI June 2019 XI (1).pdf\#page=1 $\underline{23}$

6. ICA \& EURICSE (2018). World Cooperative Monitor report 2018: Exploring the Cooperative Economy. Retrieved from https://www.ica.coop/sites/default/files/publication-files/wcm2018-printx50227290600.pdf

7. Kooperācijas attīstība lauksaimniecībā un attīstības stratēǵija 2013.-2020. gadam (2012). Tematiskais novērtējums. Nozaru ziṇojums. Rīga. Retrieved from http://laukutikls.lv/informativie-materiali/nozaru-zinojumi-2012

8. Kučinskis, J. (2004). Kooperācijas attīstība Latvijā un pasaulē. Rīga: Latvijas Hipotēku un zemes banka. 
9. Latvijas Republikas Saeima (2012). Latvijas Nacionālais attīstības plāns 2014.2020.gadam. Retrieved from https://www.pkc.gov.lv/images/NAP2020\%20dokumenti/20121220 NAP2020 aps tiprinats Saeima.pdf

10. Latvijas Republikas Saeima (2019). Kooperatīvo sabiedrību likums. Retrieved from https://likumi.lv/ta/id/298656-kooperativo-sabiedribu-likums

11. LLKA (2019). LLKA ir izstrādājusi lauksaimniecības un mežsaimniecības pakalpojumu kooperatīvo sabiedrību attīstības stratēǵiju 2021 - 2027.gadam. Retrieved from http://www.llka.lv/kooperacija strategija

12. Vedl̦a, A. (2000). Uzñēmējdarbības kurss. Rīga: Petrovskis \& Ko. 